\title{
Psikososial dan Beban Kerja Perawat - Sebuah Penelitian di Salah Satu RS Militer di Indonesia
}

\author{
Hardianto Iridiastadi ${ }^{1}$, Vera Septiawati ${ }^{2}$, Euis Nina Saparina Yuliani ${ }^{3^{*}}$, dan Hernadewita ${ }^{4}$ \\ ${ }^{1,2)}$ Institut Teknologi Bandung, Bandung \\ 3,4) Universitas Mercu Buana, Medan \\ *) e-mail korespondensi: nina.yuliani@mercubuana.ac.id \\ doi: https://doi.org/10.24843/JEI.2020.v06.i01.p03
}

article Received: 25 Mei 2020; Accepted: 14 Juni 2020; Published: 30 Juni 2020

\begin{abstract}
Abstrak
Penelitian ini bertujuan untuk mengetahui tingkat beban kerja mental dan faktor psikososial dari para perawat tingkat pelaksana di ruang rawat inap rumah sakit militer. Data diambil dari penyebaran kuesioner kepada 41 perawat tingkat pelaksana yang bertugas di ruang rawat inap. Pengukuran beban kerja mental dilakukan dengan menggunakan kuesioner National Aeronautics and Space Administration - Task-Load Index (Nasa-TLX). Pengukuran faktor psikososial dilakukan dengan menggunakan kuesioner The Copenhagen Psychosocial Questionnaire (COPSOQ II). Hasil penelitian menunjukkan bahwa nilai rerata keseluruhan beban kerja mental berada pada kategori tinggi. Nilai faktor psikososial lingkungan kerja menunjukkan hasil yang baik pada mayoritas skala penilaian. Akan tetapi, pihak rumah sakit perlu memperhatikan beberapa faktor seperti tuntutan emosi, persepsi kesehatan, kelelahan dan stres serta aspek tempo pekerjaan. Hasil penelitian ini juga menunjukkan adanya hubungan positif yang kuat dan signifikan antara dimensi kepercayaan manajemen dengan kinerja dengan $\mathrm{r}=0,545(\mathrm{p}=0,000)$. Dengan demikian, disarankan agar pihak manajemen rumah sakit tidak hanya melakukan penilaian terhadap kinerja para perawat tetapi dapat juga melakukan penilaian beban kerja mental dan faktor psikososial secara berkala agar tercipta lingkungan kerja yang kondusif.
\end{abstract}

Kata kunci: beban kerja mental, kerja shift, perawat, psikososial

\section{Psychosocial and Work Load among Nurses - A Study at An Indonesian Military Hospital}

\begin{abstract}
This study aimed to determine the level of mental workload and psychosocial factors of nurses at the executive level in in-patient rooms of a military hospital. Data were collected by distributing questionnaires to 41 nurses who served in the in-patient rooms. Measurement of mental workload was carried out using the National Aeronautics and Space Administration - Task-Load Index (Nasa-TLX) questionnaire. Measurement of psychosocial factors was carried out using the Copenhagen Psychosocial Questionnaire (COPSOQ II) questionnaire. The results showed that the average value of the overall mental workload was in the high category. The value of psychosocial factors in the work environment shows good results on the majority of the rating scales. However, the hospital needed to pay attention to several factors, such as emotional demands, health perceptions, fatigue and stress and work pace. The results of this study also showed a strong and significant positive relationship between the dimensions of management's trust and performance with $r=0.545(p=0.000)$. Thus, it is recommended that hospital management not only assess the performance of nurses, but also periodically assess mental workload and psychosocial factors in order to create a conducive work environment.
\end{abstract}


Keywords: mental workload, shift work, nurse, psychosocial

\section{PENDAHULUAN}

Salah satu pekerjaan yang memerlukan perhatian dalam beban kerja adalah keperawatan. Orang-orang yang terlibat dalam sistem keperawatan dikenal sebagai perawat. Secara lebih lengkap perawat didefinisikan sebagai seseorang yang telah lulus pendidikan tinggi keperawatan, baik di dalam maupun luar negeri yang diakui pemerintah sesuai dengan ketentuan perundang-undangan (Kementrian Kesehatan RI, 2017). Beban kerja perawat merupakan kontributor utama dari keselamatan pasien, terutama perawat di lingkungan/bagian kritis (Carayon dan Gurses, 2005).

Profesi keperawatan diketahui telah menjadi suatu profesi yang semakin kompleks dan memiliki tuntutan untuk tetap memberikan pelayanan terbaik kepada pasien. Komponen yang berkontribusi terhadap kompleksitas keperawatan adalah kebutuhan untuk merawat pasien yang memiliki kebutuhan kompleks, seperti diagnosis penyakit yang perlu dilakukan dengan ketajaman tinggi. Hal tersebut mengharuskan perawat memiliki fokus dalam proses perawatan dan keterampilan koordinasi (Potter, dkk., 2005). Perawat juga mendapat peningkatan beban kognitif (Tucker dan Spear, 2006). Beban kerja adalah salah satu faktor yang paling signifikan dalam keperawatan. Oleh karena itu, mengukur beban kerja keperawatan merupakan langkah penting untuk memahami hubungan antara beban kerja, daya ingat perawat, dan keselamatan pasien (Duffield, Roche, dan Merrick, 2006). Salah satu dimensi beban kerja yang terkait dengan keperawatan adalah beban kerja mental.

Beban kerja yang berlebihan telah diidentifikasi sebagai penyebab utama stress dan ketidakpuasan dalam tenaga kerja keperawatan (Aiken, dkk., 2001). Beban kerja yang di alami oleh perawat, terutama bagian kritis dapat berdampak pada kesehatan (cedera), kualitas kehidupan bekerja (kepuasan kerja, stres, kelelahan dan niat untuk berpindah) dan keselamatan pasien (Carayon dan Alvarado, 2007). Beban kerja yang tinggi secara tidak langsung dapat berdampak pada keselamatan pasien karena dampak negatifnya terhadap komunikasi dan penurunan kepuasan kerja, motivasi dan kelelahan.

Faktor penting lainnya dalam lingkungan kerja yang memerlukan perhatian adalah faktor psikososial dalam lingkungan kerja. Lingkungan kerja psikososial secara umum dipertimbangkan sebagai salah satu dari banyak masalah mengenai lingkungan kerja dalam masyarakat modern (Kristensen, Hannerz, Hogh, dan Borg, 2005). Pada kasus yang terjadi di salah satu rumah sakit militer, pasien tidak hanya berasal dari suatu kota besar di Indonesia, tetapi juga berasal dari daerah lain di wilayah Jawa Barat.

Jumlah pasien yang harus dilayani sangat berpengaruh terhadap kondisi dan faktor psikososial para perawatnya. Untuk menunjang kondisi beban kerja dan faktor psikososial tentunya diperlukan penilaian khusus terhadap para pegawainya, termasuk perawat di tingkat pelaksana. Sistem penilaian untuk pegawai, khususnya perawat yang dilakukan oleh pihak rumah sakit dilakukan pada aspek kinerja individu perawat. Kajian mengenai beban kerja mental dan faktor psikososial belum dilakukan oleh pihak rumah sakit. Dengan alasan demikian, rumah sakit militer perlu untuk memperhatikan beban kerja mental dan faktor psiksosisal dari perawatnya. Hal tersebut dimaksudkan agar kasus-kasus yang di alami praktisi kesehatan, khususnya perawat tidak terjadi di lingkungan kerja rumah sakit militer.

Berdasarkan penjelasan tersebut, maka penelitian ini bertujuan untuk mengevaluasi tingkat beban kerja mental dan faktor psikososial perawat pelaksana di ruang rawat inap rumah sakit militer, memberikan masukan untuk pihak manajemen rumah sakit terkait dengan beban 
kerja mental dan faktor psikososial yang dialami para perawat di tingkat pelaksana, melakukan uji korelasi untuk mengetahui hubungan antara beban kerja mental dan faktor psikososial.

Penelitian ini diharapkan dapat memberikan pengetahuan mengenai beban kerja yang dialami oleh para perawat. Dengan demikian, hal tersebut dapat dijadikan acuan oleh pihak rumah sakit dalam membagi pekerjaan atau tugas kepada para perawat sehingga pihak rumah sakit dapat memberikan pelayanan yang maksimal terhadap pasien.

\section{METODE}

Beban kerja mental para perawat di ruang rawat inap dievaluasi menggunakan instrumen berupa kuesioner Nasa-TLX. Nasa-TLX terdiri dari enam dimensi pengukuran, diantaranya beban mental, beban fisik, tekanan waktu, frustasi, kinerja dan tingkat usaha. Adapun faktor psikososial di evaluasi dengan menggunakan instrumen COPSOQ-II. COPSOQ-II terdiri dari tujuh dimensi pengukuran, diantaranya tuntutan pekerjaan, organisasi kerja dan konten pekerjaan, hubungan interpersonal dan kepemimpinan, pandangan individu pekerjaan, nilai di tempat kerja, kesehatan dan kesejahteraan serta perilaku tidak menyenangkan/menyinggung.

Penelitian diawali dengan tahap penetapan tujuan, pemilihan kuesioner, penentuan objek dan sampel, penyebaran kuesioner yang dilakukan pada bulan Mei 2018 hingga Juni 2018, pengolahan data, analisis hingga penarikan kesimpulan dan saran. Penelitian ini dilakukan di salah satu rumah sakit militer di Bandung dan dilakukan terhadap perawat tingkat pelaksana di tiga (3) ruang rawat inap yang berbeda namun memiliki karakteristik pekerjaan yang sama.

Nasa-TLX telah teruji validitas dan reliabilitasnya, termasuk dalam versi bahasa Indonesia yang telah teruji validitasnya $(\mathrm{p}=0,746)$ dan reliabilitasnya (Cronbach's Alpha 0,963 ) dalam penelitian yang telah dilakukan sebelumnya (Werdani, 2016). Penelitian ini juga menggunakan alat ukur Visual Analog Scale (VAS) untuk mengukur beban kerja mental secara keseluruhan untuk setiap shift kerja yaitu pagi, siang dan malam.

Uji validitas instrumen (kuesioner COPSOQ II) dilakukan dengan menggunakan uji Pearson. Hasil uji validitas menunjukkan bahwa dimensi yang dinyatakan tidak valid yaitu kecepatan kerja, kepuasan kerja, dan persepsi kesehatan secara umum. Pertanyaan yang dinyatakan tidak valid dapat dilakukan tindakan koreksi pada struktur kalimat yang digunakan atau menghilangkan item pertanyaan tersebut. Pada penelitian ini data yang telah dikumpulkan dilakukan koreksi karena setiap data menghasilkan informasi bagi penelitian.

Uji reliabilitas instrumen/kuesioner COPSOQ II dilakukan dengan menggunakan Cronbach's Alpha. Angka Cronbach's Alpha $<0,60$ dapat dikatakan buruk, dalam kisaran 0,70 dapat diterima dan angka di atas 0,80 dapat dikatakan baik (Sekaran dan Bougie, 2013). Hasil uji reliabilitas menunjukkan bahwa dimensi komitmen pada tempat kerja memiliki angka reliabilitas yang kurang baik $(<0,6)$, dimensi tuntutan kuantitatif, kemungkinan berkembang, penghargaan, kejelasan peran dan keadilan memiliki angka reliabilitas yang dapat diterima (sekitar 0,7 ) serta dimensi lainnya memiliki angka reliabilitas yang baik (di atas 0,8 ).

Besar sampel ditentukan dengan rumus Slovin (Indrawan dan Yaniawati (2016). Berdasarkan hasil perhitungan, jumlah sampel yang seharusnya adalah 95,8 96 orang perawat. Namun demikian, karena terkait dengan keputusan pihak rumah sakit (hal perijinan) maka sampel yang digunakan dalam penelitian ini adalah sebanyak empat puluh satu (41) orang perawat ruang rawat inap di tingkat pelaksana yang bekerja pada 3 unit berbeda dengan shift kerja yang berbeda-beda pula.

Data yang telah diperoleh dari masing-masing instrumen evaluasi selanjutnya diolah sesuai dengan metode masing-masing instrumen. NASA-TLX terdiri dari enam (6) subskala yaitu beban mental, beban fisik, tuntutan waktu, kinerja, frustrasi dan tingkat usaha. Skala dalam Nasa-TLX disajikan berupa garis yang terbagi ke dalam 20 interval yang bernilai 0-100. Nasa-TLX mengalami perkembangan / modifikasi dalam langkah pengerjaannya yaitu dengan 
menghilangkan proses pembobotan. Rating yang didapat hanya dirata-ratakan atau ditambahkan untuk mendapatkan perkiraan beban kerja secara keseluruhan (Hart, 2006).

Penilaian atas tekanan aspek psikososial di tempat kerja dilakukan dengan menggunakan kuesioner COPSOQ II yang dikembangkan oleh NRCWE, Denmark. Jenis singkat/pendek dari kuesioner COPSOQ II tepat digunakan untuk di lingkungan kerja. COPSOQ II versi pendek memiliki 40 butir pertanyaan yang mengukur 23 dimensi (Pejtersen, dkk., 2010b; Rahman, dkk., 2017). Tuntutan pekerjaan, organisasi kerja dan konten pekerjaan, hubungan interpersonal dan kepemimpinan, pandangan individu pekerjaan, nilai di tempat kerja, kesehatan dan kesejahteraan dan perilaku tidak menyenangkan / menyinggung merupakan skala-skala yang mewakili dimensi dalam kuesioner COPSOQ II. Kuesioner COPSOQ menggunakan lima (5) kategori tanggapan di setiap pertanyaan kecuali untuk dimensi kepuasan kerja dan konflik kerja-keluarga memiliki empat (4) kategori tanggapan (Rahman, dkk., 2017). Lima (5) kategori tanggapan yang digunakan dalam kuesioner penelitian ini adalah 1) selalu, sering, kadang-kadang, jarang, tidak pernah / hampir tidak pernah; 2) setiap saat, sering, kadang-kadang, jarang, tidak pernah sama sekali, 3) luar biasa, sangat baik, baik, cukup, kurang. Sementara empat (4) kategori tanggapan yang digunakan dalam penelitian ini adalah 1) sangat puas, puas, tidak puas dan sangat tidak puas; 2) ya tentu saja, sampai tingkat tertentu, hanya sangat sedikit, tidak sama sekali. Pertanyaan yang memiliki empat (4) kategori tanggapan diberi skor $0,33,3,66,7$, dan 100, sedangkan untuk pertanyaan yang berhubungan dengan lima (5) kategori tanggapan diberi skor 0, 25, 50, 75 dan 100 (Chang dan Cho, 2016).

Penilaian beban kerja secara keseluruhan diukur dengan menggunakan teknik visual analogue scale atau VAS (Heller, dkk., 2016; Tanaka, dkk., 2015). Seluruh data penelitian diperoleh dari para perawat yang tengah bekerja pada shift pagi, namun memiliki pengalaman bekerja rutin pada ketiga shift. Penggunaan data VAS semata-mata hanya ditujukan untuk melihat ada atau tidaknya perbedaan beban kerja keseluruhan antar shift kerja, sedangkan data yang diperoleh dari NASA-TLX serta COPSOC II lebih diarahkan pada penilaian tinggi/rendahnya elemen dari beban kerja mental atau aspek tekanan psikososial. Korelasi antara data NASA-TLX dan COPSOC II dilakukan untuk mengetahui bila terdapat kesesuaian antara tekanan mental dengan tekanan psikososial yang dialami oleh para perawat.

\section{HASIL DAN PEMBAHASAN}

Karakteristik responden dapat dilihat pada Tabel . Responden berasal dari 3 ruang inap berbeda, tetapi memiliki karakteristik pekerjaan yang sama. Mayoritas responden memiliki jenis kelamin wanita dengan usia 26-30 tahun. Responden umumnya belum menikah dan memiliki pengalaman kerja 0-5 tahun. Selain itu, mayoritas responden menempuh pendidikan terakhir di jenjang D3.

Terdapat 3 hal yang diperiksa, tingkat beban kerja mental, faktor psikososial, dan korelasi diantara keduanya. Kuesioner Nasa-TLX digunakan untuk menguji tingkat beban kerja mental perawat. Di sisi lain, kuesioner COPSOQ digunakan untuk mendapatkan data faktor psikososial. Korelasi diantara beban kerja dan faktor psikososial diuji menggunakan uji Spearman.

Untuk memeriksa beban kerja mental yang dirasakan, responden diminta untuk mengisi kuesioner Nasa-TLX. Hasil rekapitulasi beban kerja berdasarkan penggunaan kuesioner NasaTLX dapat dilihat pada Tabel 2. Langkah perhitungan dilakukan dengan mencari rata-rata rating yang diberikan oleh responden untuk mengestimasi nilai beban kerja keseluruhan.

Hasil evaluasi beban kerja mental menunjukkan bahwa nilai beban kerja mental secara keseluruhan mendekati 80 dan termasuk ke dalam kategori tinggi. Dimensi beban kerja mental dengan rata-rata tertinggi terdapat pada dimensi beban fisik dan diikuti tekanan waktu, beban mental, kinerja, tingkat usaha dan rata-rata terendah terdapat pada dimensi frustrasi. 
Tingginya beban kerja mental yang di alami perawat dapat disebabkan oleh adanya aktivitas berkelanjutan dari sistem saraf simpatik (Schuetz, dkk., 2008). Tingginya beban kerja mental juga dapat menyebabkan penurunan kineja (Mazur, dkk., 2012). Menurut Wickens dkk., kinerja seseorangberada di bawah tingkat beban kerja yang tinggi dapat menurun dan disebabkan oleh banyak faktor seperti keterbatasan keterampilan, kompleksitas sistem, rancangan manusia mesin yang kurang sesuai, kekurangan kesadaran situasi, komunikasi interpersonal yang tidak sesuai, proses informasi dan pembuatan keputusan yang tidak sempurna (Mazur, dkk., 2012).

Tabel 1

Statistik Karakteristik Responden

\begin{tabular}{llcc}
\hline \multicolumn{1}{c}{ Variabel } & & Frekuensi & Distribusi (\%) \\
\hline Jenis Kelamin & Pria & 4 & 9,76 \\
Usia & Wanita & 37 & 90,24 \\
& $20-25$ & 11 & 26,83 \\
& $26-30$ & 18 & 43,90 \\
& $31-35$ & 5 & 12,20 \\
Status Pernikahan & $36-40$ & 6 & 14,63 \\
Pengalaman Kerja & Sudah & 1 & 2,44 \\
& Belum & 15 & 36,59 \\
& $0-5$ & 36 & 63,41 \\
Pendidikan & $6-10$ & 4 & 78,05 \\
Terakhir & $11-15$ & 4 & 9,76 \\
& $16-20$ & 1 & 9,76 \\
& D3 & 36 & 2,44 \\
& S1 & 5 & 87,80 \\
\end{tabular}

Perawat pelaksana di ruang rawat inap bekerja dengan sistem shift (yang terdiri dari shift pagi, siang dan malam) yang jadwalnya di atur oleh kepala ruangan setiap bulannya. Jam kerja untuk shift pagi dimulai pukul 07.00 WIB hingga pukul 14.00 WIB. Jam kerja untuk shift siang dimulai dari pukul 14.00 WIB hingga pukul 21.00 WIB. Jam kerja untuk shift malam dimulai pukul 21.00 WIB hingga pukul 07.00 WIB. Alat ukur VAS digunakan untuk mengukur tingkat beban kerja keseluruhan untuk setiap shift. Rekapitulasi perhitungan dengan VAS ditampilkan pada Tabel 3.

Tabel 2

Perhitungan Nasa-TLX

\begin{tabular}{lcc}
\hline Dimensi Nasa-TLX (N=41) & Rata-rata & Standar Deviasi \\
\hline Beban Mental & 79,76 & 10,66 \\
Beban Fisik & 82,20 & 10,84 \\
Tekanan Waktu & 80,61 & 7,84 \\
Kinerja & 78,66 & 12,80 \\
Frustasi & 74,63 & 14,20 \\
Tingkat Usaha & 75,98 & 12,41 \\
Overall Workload & 78,64 & 11,91 \\
\hline
\end{tabular}

Hasil perhitungan dengan VAS pada Tabel 3 menunjukkan bahwa rata-rata beban kerja secara keseluruhan dirasakan tinggi pada saat bekerja shift malam (dengan rata-rata 82,39) dan dirasakan rendah ketika berkerja pada shift pagi (dengan rata-rata 67,70). 
Tabel 3

Rekapitulasi Perhitungan dengan VAS

\begin{tabular}{cccc}
\hline & & Rerata & $\begin{array}{c}\text { Simpang } \\
\text { Baku }\end{array}$ \\
\hline \multirow{3}{*}{ Skor VAS } & Shift Pagi & 67,70 & 22,33 \\
& Shift Siang & 77,61 & 15,17 \\
& Shift Malam & 82,39 & 12,81 \\
\hline
\end{tabular}

Dari hasil perhitungan dengan menggunakan alat ukur VAS, dilakukan uji signifikansi untuk menentukan apakah terdapat perbedaan beban kerja yang signifikan diantara shift-shift yang ada. Langkah pertama yang dilakukan dalam uji signifikansi ini adalah uji normalitas untuk menentukan jenis uji statistik yang digunakan.

Hasil perhitungan menunjukkan bahwa terdapat data beban kerja keseluruhan yang tidak berdistribusi normal, yaitu data untuk shift pagi $(\mathrm{p}=0,000)$ dan siang $(\mathrm{p}=0,000)$. Adapun jenis uji signifikansi yang digunakan untuk data tidak berdistribusi normal adalah uji Kruskal Wallis. Hipotesis yang diuji dalam uji Kruskal Wallis adalah tidak terdapat perbedaan nilai beban kerja mental keseluruhan antara shift kerja. Hasil perhitungan menunjukkan bahwa nilai signifikan $\mathrm{p}<0,05$. Oleh karena itu, dapat diartikan bahwa terdapat minimal satu nilai yang berbeda signifikan dari beban kerja mental keseluruhan untuk shift pagi, siang atau malam. Untuk mengetahui secara spesifik bagian yang memiliki nilai berbeda signifikan dapat dilakukan uji Mann-Whitney.

Hipotesis yang digunakan dalam uji Mann-Whitney adalah tidak terdapat perbedaan nilai beban kerja mental dari dua sampel shift kerja. Hasil perhitungan dapat dilihat pada Tabel 4.

Tabel 4

Uji Mann Whitney Data VAS Keseluruhan setiap Shift

\begin{tabular}{lll}
\hline Shift Kerja & $\mathrm{p}$ & Keputusan \\
\hline Pagi - Siang & 0,009 & Ada Perbedaan \\
Pagi - Malam & 0,000 & Ada Perbedaan \\
Siang - Malam & 0,057 & Tidak Ada Perbedaan \\
\hline
\end{tabular}

Hasil perhitungan pada Tabel 4, menunjukkan bahwa terdapat perbedaan secara statistik untuk nilai beban kerja mental keseluruhan antara shift pagi-siang dan shift pagi-malam $(\mathrm{p}<0,05)$. Akan tetapi, tidak terdapat perbedaan secara statistik pada nilai beban kerja mental secara keseluruhan untuk shift siang - malam $(\mathrm{p}>0,05)$.

Setelah mengetahui bahwa terdapat perbedaan beban kerja yang signifikan antara shift kerja pagi dengan shift malam dan siang, dapat disimpulkan bahwa para perawat merasakan beban mental keseluruhan paling tinggi ketika bekerja pada shift malam. Beberapa hal yang mungkin dapat menyebabkan beban kerja pada shift malam bernilai paling tinggi di antaranya jam kerja yang lebih panjang, jumlah perawat yang dialokasikan pada shift malam tidak sebanyak shift lainnya, rasa kantuk. Selain itu, hasil uji statistik menunjukkan hasil bahwa tidak terdapat perbedaan secara statistik untuk beban kerja mental keseluruhan antara shift siang dan malam.

Hal ini perlu menjadi perhatian khusus karena penelitian terkait shift kerja menyebutkan bahwa jumlah shift kerja malam per bulan berhubungan positif dengan insomnia. Hasil penelitian Flo, dkk. (2012) menunjukkan bahwa jumlah bekerja jam malam merupakan faktor risiko penting dari gangguan kerja shift, termasuk insomnia. Hal tersebut yang diperkirakan dapat menyadi penyebab mengapa beban kerja malam dirasakan memiliki tingkat beban kerja mental secara keseluruhan yang tinggi. 
Kuesioner COPSOQ digunakan untuk mendapatkan data faktor psikososial. Data perilaku tidak menyenangkan/menyinggung diolah dengan mencari nilai presentase, sedangkan data lainnya diolah dengan cara menghitung nilai rerata dan simpang baku untuk setiap dimensi. Rekapitulasi hasil perhitungan dapat dilihat pada Tabel 5.

Tabel 5

Perhitungan Data Faktor Psikososial

\begin{tabular}{|c|c|c|c|}
\hline \multicolumn{2}{|c|}{$\begin{array}{c}\text { Komponen Skala Dan Dimensi Kuesioner } \\
\text { COPSOQ II }(\mathrm{N}=41)\end{array}$} & \multirow{2}{*}{$\begin{array}{r}\text { Rerata } \\
37,20\end{array}$} & \multirow{2}{*}{$\begin{array}{c}\text { Simpang Baku } \\
22,99\end{array}$} \\
\hline Tuntutan Pekerjaan & Tuntutan kuantitatif & & \\
\hline & Kecepatan kerja & 68,90 & 22,07 \\
\hline & Tuntutan emosi & 50,91 & 20,95 \\
\hline Organisasi Kerja dan & Pengaruh & 77,74 & 24,85 \\
\hline \multirow[t]{3}{*}{ Konten Pekerjaan } & $\begin{array}{l}\text { Kemungkinan } \\
\text { berkembang }\end{array}$ & 88,72 & 16,74 \\
\hline & Arti kerja & 89,63 & 15,69 \\
\hline & $\begin{array}{l}\text { Komitmen pada tempat } \\
\text { kerja }\end{array}$ & 77,74 & 28,33 \\
\hline Hubungan & Prediktabilitas & 82,93 & 20,74 \\
\hline Interpersonal & Penghargaan & 78,96 & 23,40 \\
\hline \multirow[t]{3}{*}{ Kepemimpinan } & Kejelasan peran & 85,37 & 18,82 \\
\hline & $\begin{array}{l}\text { Kualitas } \\
\text { kepemimpinan }\end{array}$ & 78,66 & 23,61 \\
\hline & $\begin{array}{l}\text { Dukungan sosial dari } \\
\text { atasan }\end{array}$ & 81,40 & 21,09 \\
\hline Pandangan Individu & Kepuasan kerja & 65,07 & 7,28 \\
\hline Pekerjaan & $\begin{array}{l}\text { Konflik Kerja- } \\
\text { Keluarga }\end{array}$ & 38,19 & 18,25 \\
\hline Nilai di Tempat Kerja & $\begin{array}{l}\text { Kepercayaan pihak } \\
\text { manajemen }\end{array}$ & 72,56 & 21,38 \\
\hline \multirow{4}{*}{$\begin{array}{l}\text { Kesehatan dan } \\
\text { Kesejahteraan }\end{array}$} & Keadilan & 78,96 & 22,39 \\
\hline & $\begin{array}{l}\text { Persepsi kesehatan } \\
\text { secara umum }\end{array}$ & 56,71 & 11,21 \\
\hline & Kelelahan & 57,32 & 15,46 \\
\hline & Stress & 47,97 & 15,32 \\
\hline
\end{tabular}

Ilic, Arandjelovic, Jovanovic, dan Nesic (2017) mengungkapkan bahwa batas rendah nilai stress berada pada nilai kurang dari 40 dan batas tinggi berada pada nilai diatas 60 . Hasil perhitungan yang diperlihatkan pada Tabel 5 menunjukkan bahwa secara rata-rata dimensi tuntutan kuantitatif dan konflik kerja-keluarga termasuk kedalam kategori rendah. Dimensi yang termasuk kategori sedang adalah tuntutan emosi, persepsi kesehatan secara umum, kelelahan dan stress. Sedangkan, dimensi yang termasuk kategori tinggi adalah kecepatan kerja, pengaruh, kemungkinan berkembang, arti kerja, komitmen pada tempat kerja, prediktabilitas, penghargaan, kejelasan peran, kualitas kepemimpinan, dukungan sosial dari atasan, kepuasan kerja, kepercayaan pihak manajemen dan keadilan. Faktor utama yang memerlukan perhatian lebih dari pihak rumah sakit adalah kategori kecepatan kerja yang mengindikasikan bahwa tempo/waktu pekerjaan berada dalam kategori tinggi.

Faktor psikososial yang dirasakan oleh para perawat pelaksana di ruang rawat inap disebabkan banyaknya pekerjaan yang harus dilakukan perawat dalam satu waktu sehingga fokus dan interaksi dalam melakukan pekerjaan semakin berkurang. Adanya keterbatasan waktu dalam komunikasi dengan dokter mengenai kondisi pasien dan kurangnya komunikasi 
dengan perawat pada shift sebelumnya membuat para perawat merasa terhambat dalam melakukan pekerjaanya, terutama dalam membaca data yang berkaitan dengan pasien. Jika komunikasi tidak diperbaiki, maka hal tersebut dapat berdampak pada keputusan yang tidak maksimal terkait penanganan pasien. Dalam waktu-waktu tertentu, tingkat stress yang di alami perawat dapat disebabkan oleh adanya kegiatan lain bersifat resmi yang dilakukan sebelum bekerja (misalnya kegiatan pelatihan untuk para perawat). Hal tersebut dapat berdampak pada kinerja perawat karena perawat merasa tingkat fokusnya berkurang dan mengalami kelelahan setelah menjalani pelatihan.

Kecepatan kerja tinggi yang dialami oleh perawat disebabkan oleh adanya keharusan perawat yang melayani pasien secara tepat waktu, contohnya perawat harus memberi obat secara rutin kepada pasien. Sebelum memberi obat kepada pasien, hal yang perlu dilakukan oleh para perawat adalah memastikan ketersediaan obat di apotek dan memeriksa kembali obat sebelum diberikan kepada pasien agar tidak terjadi kesalahan dalam pemberian obat. Walaupun pekerjaan tersebut tidak dilakukan sepanjang hari dan tidak terus menerus, setiap pekerjaan tersebut menuntut tingkat ketelitian yang tinggi dan dilakukan dalam satu waktu yang bersamaan.

Skala perilaku tidak menyenangkan/menyinggung tidak diolah dengan mencari nilai ratarata dan standar deviasi seperti skala lainnya, tetapi pengolahan dilakukan dengan cara mencari nilai persentase jumlah perawat yang mengalami perilaku tidak menyenangkan/menyinggung. Rekapitulasi perhitungan persentase skala perilaku tidak menyenangkan/menyinggung dapat dilihat pada Tabel 6.

Tabel 6

Presentase Perilaku Tidak Menyenangkan / Menyinggung

\begin{tabular}{llcc}
\hline \multicolumn{1}{c}{ Skala } & \multicolumn{1}{c}{ Dimensi } & Jumlah & Presentase \\
\hline Perilaku tidak menyenangkan & Kekerasan/Pelecehan Seksual & 2 & $4,88 \%$ \\
/ menyinggung (N=41) & Ancaman Kekerasan & 1 & $2,44 \%$ \\
& Kekerasan Fisik & 1 & $2,44 \%$ \\
& Intimidasi (Bullying) & 7 & $17,07 \%$ \\
\hline
\end{tabular}

Hasil evaluasi skala perilaku tidak menyenangkan/menyinggung menunjukkan bahwa jenis perilaku tidak menyenangkan/menyinggung yang paling banyak di alami para perawat adalah intimidasi (17,07\%), diikuti oleh kekerasan/pelecehan seksual $(4,88 \%)$, ancaman kekerasan $(2,44 \%)$ dan kekerasan fisik (2,44\%). Dalam penelitian ini tidak bisa di dapat informasi dari siapa para perawat mendapatkan perlakuan intimidasi. Namun, Chang dan Cho (2016) mengungkapkan secara umum dapat diketahui bahwa kekerasan di rumah sakit biasanya bersumber dari pasien, keluarga pasien atau rekan kerja. Penemuan tersebut diperkuat dengan penelitian yang dilakukan oleh Christlevica dkk. (2016) terhadap perawat Instalasi Gawat Darurat di salah satu Rumah Sakit di salah satu kota besar di Indonesia. Hasil penemuan tersebut mengungkapkan bahwa pelaku kekerasan terhadap perawat selain pasien juga keluarga pasien dan dokter. Penyebab kekerasan yang terjadi dikarenakan ketidakpuasan dari pasien, seperti merasa tersinggung, perawat terlalu banyak bertanya atau pelayanan yang lama. Adapun penyebab kekerasan oleh dokter dikarenakan ketidakpuasan seperti penjelasan yang kurang, perawat merasa tidak adil, prosedur yang dilakukan perawat sangat lama, kesibukan yang berlebihan, dan bercanda yang berlebihan.

Uji korelasi dilakukan untuk mengetahui hubungan antar dimensi beban kerja dan faktor psikososial menggunakan uji Spearman. Nilai kekuatan korelasi dikatakan lemah jika nilai absolut korelasi kurang dari 0,3, dikatakan sedang jika berada diantara nilai 0,3 dan 0,5 dan dikatakan tinggi apabila melebihi nilai 0,5 (Lima dan Coelho, 2018). Korelasi antara 6 dimensi Nasa-TLX dan 23 dimensi faktor psikososial diuji menggunakan uji Spearman dengan bantuan 
SPSS. Hipotesis yang digunakan dalam uji korelasi ini adalah apakah tidak ada hubungan antara dimensi faktor psikososial dan beban kerja. Pengambilan keputusan yang digunakan adalah menggunakan nilai signifikansi 0,05. Rangkuman uji korelasi dapat dilihat pada Tabel 7.

Tabel 7

Hasil Uji Korelasi Beban Kerja Mental dengan Faktor Psikososial

\begin{tabular}{|c|c|c|c|c|c|c|}
\hline & $\mathrm{BM}$ & $\mathrm{BF}$ & TW & $\mathrm{K}$ & FR & $\mathrm{TU}$ \\
\hline $\begin{array}{l}\text { Tuntutan } \\
\text { kuantitatif }\end{array}$ & $\begin{array}{c}-0,04 \\
(p=0,806)\end{array}$ & $\begin{array}{c}-0,119 \\
(p=0,457)\end{array}$ & $\begin{array}{c}-0,053 \\
(p=0,742)\end{array}$ & $\begin{array}{c}-0,285 \\
(p=0,071)\end{array}$ & $\begin{array}{c}0,086 \\
(p=0,594)\end{array}$ & $\begin{array}{c}-0,160 \\
(p=0,317)\end{array}$ \\
\hline Kecepatan kerja & $\begin{array}{c}0,158 \\
(p=0,324)\end{array}$ & $\begin{array}{c}-0,214 \\
(p=0,180)\end{array}$ & $\begin{array}{c}-0,032 \\
(p=0,845)\end{array}$ & $\begin{array}{c}-0,065 \\
(p=0,687)\end{array}$ & $\begin{array}{c}0,475 \\
(p=0,002)\end{array}$ & $\begin{array}{c}-0,143 \\
(p=0,374)\end{array}$ \\
\hline Tuntutan emosi & $\begin{array}{c}-0,109 \\
(\mathrm{p}=0,499)\end{array}$ & $\begin{array}{c}0,044 \\
(p=0,785)\end{array}$ & $\begin{array}{c}0,004 \\
(p=0,979)\end{array}$ & $\begin{array}{c}-0,310 \\
(p=0,049)\end{array}$ & $\begin{array}{c}-0,308 \\
(p=0,050)\end{array}$ & $\begin{array}{c}-0,129 \\
(p=0,420)\end{array}$ \\
\hline Pengaruh & $\begin{array}{c}0,356 \\
(p=0,022)\end{array}$ & $\begin{array}{c}-0,049 \\
(\mathrm{p}=0,759)\end{array}$ & $\begin{array}{c}0,227 \\
(p=0,153)\end{array}$ & $\begin{array}{c}0,185 \\
(p=0,246)\end{array}$ & $\begin{array}{c}0,372 \\
(p=0,017)\end{array}$ & $\begin{array}{c}0,091 \\
(p=0,570)\end{array}$ \\
\hline $\begin{array}{c}\text { Kemungkinan } \\
\text { berkembang }\end{array}$ & $\begin{array}{c}0,295 \\
(p=0,061)\end{array}$ & $\begin{array}{c}0,101 \\
(p=0,529)\end{array}$ & $\begin{array}{c}0,150 \\
(p=0,351)\end{array}$ & $\begin{array}{c}0,204 \\
(p=0,201)\end{array}$ & $\begin{array}{c}0,230 \\
(p=0,147)\end{array}$ & $\begin{array}{c}0,172 \\
(p=0,283)\end{array}$ \\
\hline Arti kerja & $\begin{array}{c}0,187 \\
(p=0,241)\end{array}$ & $\begin{array}{c}0,097 \\
(p=0,548)\end{array}$ & $\begin{array}{c}0,090 \\
(p=0,576)\end{array}$ & $\begin{array}{c}0,170 \\
(p=0,287)\end{array}$ & $\begin{array}{c}0,099 \\
(p=0,539)\end{array}$ & $\begin{array}{c}0,185 \\
(p=0,246)\end{array}$ \\
\hline $\begin{array}{l}\text { Komitmen pada } \\
\text { tempat kerja }\end{array}$ & $\begin{array}{c}-0,068 \\
(p=0,672)\end{array}$ & $\begin{array}{c}-0,223 \\
(p=0,161)\end{array}$ & $\begin{array}{c}-0,017 \\
(p=0,917)\end{array}$ & $\begin{array}{c}-0,047 \\
(p=0,770)\end{array}$ & $\begin{array}{c}0,058 \\
(p=0,719)\end{array}$ & $\begin{array}{c}-0,321 \\
(p=0,041)\end{array}$ \\
\hline Prediktabilitas & $\begin{array}{c}0,166 \\
(p=0,301)\end{array}$ & $\begin{array}{c}0,148 \\
(p=0,356)\end{array}$ & $\begin{array}{c}0,159 \\
(p=0,319)\end{array}$ & $\begin{array}{c}0,418 \\
(p=0,006)\end{array}$ & $\begin{array}{c}-0,099 \\
(p=0,538)\end{array}$ & $\begin{array}{c}0,164 \\
(p=0,304)\end{array}$ \\
\hline Penghargaan & $\begin{array}{c}0,063 \\
(p=0,697)\end{array}$ & $\begin{array}{c}-0,044 \\
(p=0,784)\end{array}$ & $\begin{array}{c}0,075 \\
(p=0,642)\end{array}$ & $\begin{array}{c}0,241 \\
(p=0,128)\end{array}$ & $\begin{array}{c}-0,297 \\
(p=0,059)\end{array}$ & $\begin{array}{c}-0,061 \\
(p=0,753)\end{array}$ \\
\hline Kejelasan peran & $\begin{array}{c}-0,227 \\
(p=0,153)\end{array}$ & $\begin{array}{c}-0,032 \\
(p=0,841)\end{array}$ & $\begin{array}{c}0,01 \\
(p=0,951)\end{array}$ & $\begin{array}{c}-0,184 \\
(p=0,251)\end{array}$ & $\begin{array}{c}-0,202 \\
(p=0,206)\end{array}$ & $\begin{array}{c}-0,294 \\
(p=0,062)\end{array}$ \\
\hline $\begin{array}{c}\text { Kualitas } \\
\text { kepemimpinan }\end{array}$ & $\begin{array}{c}-0,187 \\
(p=0,241)\end{array}$ & $\begin{array}{c}0,092 \\
(p=0,568)\end{array}$ & $\begin{array}{c}-0,03 \\
(\mathrm{p}=0,852)\end{array}$ & $\begin{array}{c}-0,012 \\
(p=0,942)\end{array}$ & $\begin{array}{c}-0,232 \\
(p=0,144)\end{array}$ & $\begin{array}{c}0,005 \\
(p=0,974)\end{array}$ \\
\hline $\begin{array}{c}\text { Dukungan sosial } \\
\text { dari atasan }\end{array}$ & $\begin{array}{c}-0,165 \\
(\mathrm{p}=0,301)\end{array}$ & $\begin{array}{c}0,013 \\
(\mathrm{p}=0,935)\end{array}$ & $\begin{array}{c}-0,059 \\
(\mathrm{p}=0,715)\end{array}$ & $\begin{array}{c}0,036 \\
(p=0,822)\end{array}$ & $\begin{array}{c}-0,191 \\
(p=0,231)\end{array}$ & $\begin{array}{c}0,074 \\
(\mathrm{p}=0,646)\end{array}$ \\
\hline
\end{tabular}

Hasil perhitungan menunjukkan bahwa pada dimensi skala tuntutan pekerjaan yang memiliki hubungan adalah tuntutan emosi dan kinerja, tuntutan emosi dan frustrasi serta kecepatan kerja dan frustrasi. Sedangkan pada dimensi skala organisasi kerja dan konten pekerjaan, terdapat hubungan antara pengaruh dan beban mental, pengaruh dan frustrasi, serta komitmen pada tempat kerja dengan tingkat usaha.

Untuk dimensi skala hubungan interpersonal dan kepemimpinan, terdapat korelasi diantara prediktabilitas dan kinerja. Dimensi lain yaitu skala pandangan individu pekerjaan menunjukkan adanya hubungan diantara kepuasan kerja dan beban mental, serta kepuasan kerja dan kinerja. Di dalam dimensi skala nilai di tempat kerja, korelasi terjadi diantara kepercayaan pihak manajemen dan beban mental, kepercayaan pihak manajemen dan tekanan waktu, kepercayaan pihak manajemen dan tingkat usaha serta keadilan dan beban fisik, kepercayaan pihak manajemen dan kinerja. Hubungan lain ditemukan dalam dimensi skala kesehatan dan kesejahteraan, yaitu hubungan persepsi kesehatan secara umum dan beban fisik, persepsi kesehatan secara umum dan tekanan waktu, serta stress dan kinerja.

Terakhir, pada dimesi skala perilaku tidak menyenangkan / menyinggung, terdapat korelasi diantara kekerasan seksual dengan beban mental, kekerasan seksual dengan beban fisik, kekerasan seksual dan tekanan waktu, kekerasan seksual dan kinerja, serta intimidasi dan frustrasi. 
Hasil evaluasi korelasi menunjukkan korelasi terkuat adalah diantara kepercayaan pihak manajemen dan kinerja. Hal tersebut menunjukkan bahwa kepercayaan pihak manajemen meningkat seiring dengan peningkatan kinerja para perawat. Penelitian lain mengungkapkan adanya hubungan antara kinerja dengan faktor lain. Zahavy (2004) dan Roud dkk. (2005) menyatakan bahwa kinerja para perawat dipengaruhi oleh ketegangan kerja yang tinggi, kekurangan kemampuan dan pelatihan, kurang cukupnya umpan balik yang diberikan, buruknya komunikasi dan dukungan atasan (Wazqar, Kerr, Regan, dan Orchard, 2017). Selain itu, Wazqar dkk. (2017) mengungkapkan adanya hubungan negatif dan signifikan antara kinerja dan ketegangan kerja di antara perawat dari unit yang berbeda dalam penelitian yang dilakukan oleh Nabirye dkk. (2011), Azizollah dkk. (2013), Donkor (2013), Muaza(2013), Fathi dkk. (2012). Sementara itu AbuAlRub (2002) dalam penelitian yang dilakukan terhadap para perawat mengungkapkan adanya hubungan antara kinerja dan ketegangan kerja.

\section{SIMPULAN}

Hasil penelitian ini menunjukkan tiga temuan utama. Pertama, tingkat beban kerja mental berada pada tingkat menengah dan tinggi. Beban kerja mental yang tinggi secara khusus dilaporkan pada aspek tuntutan fisik dan waktu kerja. Kedua, dari perspektif tekanan psikososial, tekanan tinggi dirasakan aspek organisasional dan hubungan interpersonal. Elemen arti kerja, peluang untuk berkembang, merupakan elemen yang dianggap memberikan tekanan tinggi. Aspek kesehatan dan kesejahteraan dapat dianggap telah memadai. Perlu dicatat, namun demikian, bahwa terdapat sejumlah perawat yang melaporkan adanya intimidasi dan kekerasan di tempat kerja. Temuan seperti ini nampak belum pernah dilaporkan di berbagai penelitian di Indonesia, dan fenomena ini tentunya sangat penting untuk dicermati. Terakhir, tingkat beban kerja secara keseluruhan berkaitan dengan shift kerja. Shift kerja pagi dianggap memiliki beban kerja paling rendah, sedangkan shift kerja malam dianggap sebagai waktu kerja dengan beban kerja keseluruhan paling tinggi.

Pihak manajemen rumah sakit tentunya dapat memanfaatkan hasil penelitian ini dalam merancang kondisi kerja yang lebih kondusif bagi para perawat. Salah satu hal yang harus segera dilakukan adalah memastikan bahwa intimidasi (bullying) di tempat kerja dapat ditekan serendah-rendahnya. Hal ini dapat dilakukan melalui penerapan peraturan dan kebijakan yang mengatur hubungan profesional antar perawat dengan kolega kerja maupun pasien dan keluarganya. Beban kerja mental dan tekanan psikososial yang cukup tinggi bagi perawat rumah sakit bukanlah sesuatu hal yang baru di literatur, namun harus tetap mendapatkan perhatian dari manajemen rumah sakit. Evaluasi beban kerja secara berkala (tahunan) dapat digunakan sebagai metode surveilans, yang hasilnya lebih jauh dapat dimanfaatkan dalam menentukan strategi intervensi yang tepat dalam konteks pengelolaan human capital. Perlu dicatat bahwa penelitian ini memiliki sejumlah keterbatasan, seperti perbedaan karakteristik dari satu unit kerja ke unit kerja yang lain (misalnya apotek vs. instalasi gawat darurat). Dengan demikian, hasil penelitian ini mungkin saja tidak berlaku bagi unit-unit kerja tersebut. Kajian sejenis perlu dilakukan untuk unit-unit lain di rumah sakit dalam penelitian ini.

\section{DAFTAR PUSTAKA}

Abu Al Rub, R.F. 2004. Job Stress, Job Performance, and Social Support Among Hospital Nurses. Journal Of Nursing Scholarship, Vol. 36(1):73-78.

Aiken, L. H., Clarke, S. P., Sloane, D. M., Sochalski, J. A., Busse, R., Clarke, H., Giovannetti, P., Hunt, J., Rafferty, A.M., dan Shamian, J. 2001. Nurses' Reports On Hospital Care In Five Countries. Health Affairs, Vol. 20(3):43-53. 
Carayon, P., dan Alvarado, C. J. 2007. Workload and Patient Safety Among Critical Care Nurses. Critical Care Nursing Clinic of North America, Vol. 19:121-129.

Carayon, P., dan Gurses, A. 2005 . A Human Factors Engineering Conceptual Framework Of Nursing Workload And Patient Safety In Intensive Care Units. Intensive and Critical Care Nursing, Vol. 21:284-301.

Chang, H. E., dan Cho, S.H. 2016. Workplace Violence and Job Outcomes of Newly Licensed Nurses. Asian Nursing Research, Vol. 10:271-276.

Duffield, C., Roche, M., dan Merrick, E. T. 2006. Methods Of Measuring Nursing Workload In Australia. Collegian, Vol. 3(1):16-22.

Flo, E., P. S., Mageroy, N., Moen, B. E., Gronli, J., Nordhus, I. H., dan Bjorvatn, B. 2012. Shift Work Disorder in Nurses - Assessment, Prevalence and Related Health Problems. PLoS ONE, Vol. 7(4):e33981.

Hart, S. G. 2006. Nasa-Task Load Index (Nasa-TLX). 20 Years later.

Heller, G. Z., Manuguerra, M., dan Chow, R. 2016. How to Analyze the Visual Analog Scale : Myths, Truths and Clinical Relevance. Scandinavian Journal of Pain, Vol. 13:67-75.

Ilic, I. M., Arandjelovic, M. Z., Jovanovic, J. M., dan Nesic, M. M. 2017. Relationship of Work - Related Psychosocial Risks, Stress, Individual Factors and Burnout - Questionnaire Survey Among Emergency Physicians and Nurses. Medycyna Pracy, Vol. 68(2):167178.

ILO. 1986. Psychosocial Factors At Work : Recognition and control. Geneva: International Labour Office.

Indriawan, R., dan Yaniawati, P. 2016. Metodologi Penelitian. Bandung: Refika Aditama.

Kementrian Kesehatan RI. 2017. InfoDATIN Pusat Data dan Informasi Kementrian Kesehatan RI. pp. 1-10.

Kristensen, Hannerz, Hogh, dan Borg. 2005. The Copenhagen Psychosocial Questionnaire - A Tool for The Assessment And Improvement of The Psychosocial Work Environment. Scandinavian Journal of Work, Environment dan Health, Vol. 31(6):438-449.

Mazur, L.M., Mosaly, P.R., Jackson, M., Chang, S. X., Burkhardt, K.D., Adams, R.D., dan Marks, L.B. 2012. Quantitative Assessment of Workload and Stressors in Clinical Radioation Oncology. International Journal of Radiation Oncology Biology Physics, Vol. 83(5):e571-e576.

Pejtersen, J.H., Kristensen, T.S., Borg, V., dan Bjorner, J.B. 2010. The Second Version of The Copenhagen Psychosocial Questionnaire. Scandinavian Journal of Public Health, Vol. 38:8-24.

Potter, P., Wolf, L., Boxerman, S., Grayson, D., Sledge, J., Dunagan, C., dan Evanoff, B. 2005. Understanding the Cognitive Work of Nursing in the Acute Care Environment. Journal of Nursing Admisnistration, Vol. 35(7/8):327-335.

Rahman, H. A., Abdul-Mumin, K., Naing, L. 2017. Psychosocial Work Stressor, work Fatigue, and Musculoskeletal Disorders : Comparison between Emergency and Critical Care Nurses in Brunei Public Hospitals. Asian Nursing Research, Vol. 11:13-18.

Roud, D., Giddings, S., dan Koziol-McLain, J. 2005. A longitudinal survey of nurses' selfreported performance during an entry to practice programme. Nurs Praxis $N$ Z. Inc, Vol. 21(2):37-46.

Sekaran, U., dan Bougie, R. (2013). Research Methods for Business. United Kingdom: Wiley. Schuetz, M., Gockel, I., Beardi, J., Hakman, P., Dunschede, F., Moenk, S., dan Junginger. 2008. Three Different Types of Surgeon-Specific Stress Reactions Identified by Laparoscopic Simulation in A Virtual Scenario. Surgical Endoscopy, Vol. 22:12631267. 
Tanaka, N., Ohno, Y., Hori, M., Utada, M., Ito, K., Suzuki, T., dan Furukawa, F. 2015. Predicting Preoperative Hemodynamic Changes Using the Visual Analog Scale. Journal of PeriAnesthesia Nursing, Vol. 30(6):460-467.

Tucker, A.L., dan Spear, S.J. 2006. Operational Failures and Interruptions in Hospital Nursing. Health Services Research, Vol. 41(3):643-662.

Wazqar, D.Y., Kerr, M., Regan, S., dan Orchard, C. 2017. An Integrative Review of The Influence of Job Strain and Coping on Nurse's Work Performance ; Understanding The Gaps in Oncology Nursing Research. International Journal of Nursing Sciences, Vol. 4:418-429.

Werdani, Y.D. 2016. Pengaruh Beban Kerja Mental Perawat Terhadap Tingkat Kepuasan Pasien Di Ruang Rawat Inap Rumah Sakit Swasta Di Surabaya. Ners LENTERA, Vol. 4(2):97 - 105. 